\title{
PENGARUH BRAND IMAGE, INSTAGRAM ADVERTISING MEDIA DAN PRODUCT QUALITY TERHADAP KEPUTUSAN PEMBELIAN PRODUK KOPI DI BLEND COFFE PADANG
}

\author{
Jeniver Pribadi, Maria Magdalena \\ STIE"KBP" \\ jeniver.pribadi@gmail.com
}

\begin{abstract}
ABSTRAK
Penelitian ini memiliki rumusan masalah: 1 Seberapa besar pengaruh brand image terhadap keputusan pembelian produk blend coffe, 2 Seberapa besar pengaruh Instagram advertising media terhadap keputusan pembelian produk blend coffe, 3 Seberapa besar pengaruh product quality terhadap keputusan pembelian produk blend coffe. Penelitian ini dikategorikan sebagai penelitian deskriptif kuantitatif, dimana instrumen penelitian ini berupa kuesioner. Populasi dalam penelitian ini adalah pelangan di café blend Teknik pengambilan sampel mengunakan rumus slovin, dengan jumlah sampel 100 responden. Kemudian dilakukan analisis terhadap data-data yang diperoleh meliputi uji validitas, uji reliabilitas,dan uji TCR, uji asumsi klasik lewat uji normalitas data, uji heteroskedastistas dan uji multikolinearitas,uji regresi berganda, uji hipotesis lewat uji $\mathrm{F}$, uji $\mathrm{t}$ dan uji analisis koefisien determinasi (R2), diolah sehingga menghasilkan persamaan regresi sebagai berikut : $Y=\mathbf{1 , 4 2 0}+\mathbf{0 , 4 8 8} X_{\mathbf{1}}+\mathbf{0 , 3 6 9} \mathbf{X}_{\mathbf{2}}+\mathbf{0 , 6 3 6} \mathrm{X}_{\mathbf{3}}$. Hasil analisis mendapatkan bahwa ketiga factor citra merek, media iklan Instagram dan kulitas produk memiliki pengaruh positif dan signifikan terhadap Keputusan pembelian. Pengujian hipotesis menggunakan uji t menunjukkan bahwa ketiga variabel independen yang diteliti terbukti secara signifikan mempengaruhi variabel dependen Keputusan pembelian. Kemudian melalui uji $\mathrm{F}$ dapat diketahui bahwa variable citra merek, media iklan Instagram berpengaruh signifikan secara bersamasama dalam Keputusan pembelian, angka $\mathrm{R}^{2}$ sebesar 0,296 hal ini menggandung arti bahwa pengaruh variabale citra merek, media iklan Instagram dan kulitas produk secara simulat terhadap Keputusan pembelian sebesar 29,6\%.
\end{abstract}

Kata kunci : citra merek, media iklan Instagram, kulitas produk, Keputusan pembeli.

\section{PENDAHULUAN}

Sejalan dengan perkembngan ternologi yang semakin maju saat ini penggunaan internet sudah tidak asing lagi untuk memasarkan suatu produk. E-commerce adalah sistem penjual yang berkembang setelah ditemukan internet. Sistem pemasaran atau penjualan dari Ecommerce bisa menjangkau seluruh dunia. Dinamika dalam dunia usaha yang semakin menantang, membuat perusahaan harus dapat menjawab tantangan pasar dan memanfaatkan tantangan tersebut sebagai peluang untuk dapat bertahan dimasa yang akan datang. Model pemasaran yang saat ini sedang menjadi tren adalah social media marketing. Media sosial menawarkan kesempatan yang tak tertandingi bagi pemasar dan menyediakan lahan yang strategis untuk mengiklankan produk dan menerapkan taktik pemasaran lainnya. Instagram adalah aplikasi 
berbagi foto dan video yang dapat diunduh gratis bagi pengguna $\mathrm{iOS}$ dan Android.

Salah satu brand yang memanfaatkan media sosial Instagram dengan baik untuk media iklan adalah blend coffee (@blendcoffeetea), dalam kondisi persaingan uasah yang semakin ketat saat ini perusahaan perlu memanfaatkan sumber dayanya dengan optimal, termasuk berusaha menciptakan atau melakukan rekayasa yang dapat mempengaruhi persepsi konsumen, misalnya melalui brend image produknya.

Fransisca (2010) dalam penelitannya menyimpulkan bahwa brand image memiliki pengaruh yang signifikan terhadap keputusan pembelian . Produk harus memiliki tingkat kualitas tertentu karena produk dibuat untuk memenuhi selera konsumen atau memuaskan pemakaiannya. Konsumen harus diyakinkan mengenai apa yang ditawarkan pada mereka, terutama mengenai quality, sampai akhirnya memutuskan untuk membeli suatu produk. Garvin dan A. dale timpe (1990) dalam Alma (2011) quality adalah keunggulan yang dimiliki oleh produk tersebut, ragam konsumen secara psikologi tercermin dari motivasi, sikap dan persepsi mereka terhadap sebuah produk.

\section{TUJUAN PENELITIAN}

1. Untuk menguji pengaruh brand image terhadap keputusan pembelian produk blend coffe.

2. Untuk menguji pengaruh Instagram advertising media terhadap keputusan pembelian produk blend coffe.
3. Untuk menguji pengaruh product quality terhadap keputusan pembelian produk blend coffe.

\section{LANDASAN TEORI \\ Keputusan Pembelian}

Keputusan

pembelian

merupakan suatu proses pengambilan keputusan akan pembelian yang mencakup penentuan apa yang akan dibeli atau tidak melakukan pembelian dan keputusan itu diperoleh dari kegiatan-kegiatan sebelumnya

(Sofjan Assauri,2004:141).

\section{Brand Image}

Menurut Tjiptono (1997) brand image yakni deskripsi tentang asosiasi dan keyakinan konsumen terhadap merek tertentu. Menurut Kotler (2008) brand image adalah persepsi dan keyakinan yang dilakukan oleh konsumen, seperti tercermin dalam asosiasi yang terjadi dalam memori konsumen.

\section{Instagram}

\begin{tabular}{lrr}
\multicolumn{1}{c}{ Instagram adalah } & sebuah \\
aplikasi berbagi & foto yang \\
memungkinkan & pengguna
\end{tabular} mengambil foto, menerapkan filter digital, dan membagikannya ke berbagai layanan jejaring sosial, termasuk milik Instagram sendiri (Frommer, 2010).

\section{Product Quality}

Menurut McCarthy (1993)

product quality berarti kemampuan suatu produk untuk memenuhi kebutuhan atau keperluan pelanggan atau konsumen. Sedangkan Kotler (2001) menyatakan product quality berarti kemampuan produk untuk melaksanakan fungsinya.

\section{Penelitian Terdahulu}

1. (Sulistyawati, 2011) dengan judul Analisis Pengaruh Citra Merek dan Kulitas Produk Terhadap Keputusan 
Pembelian Laptop Merek Acer Di Kota Semarang. Menyatakan bahwa kualitas produk dan citra merek berpengaruh positif terhadap keputusan pembelian produk laptop merek Acer.

2. (Zimri et al., 2013) dalam Periklanan dan Citra Merek Pengaruhnya Terhadp Keputusan Pembelian Kendaraan Bermotor Yamaha. Menytakan bahwa eriklanan dan Citra Merek berpengaruh secara simultan terhadap keputusan pembelian

\section{METODE PENELITIAN Jenis Penelitian}

Penelitian ini merupakan penelitian survei, dimana informasi yang dikumpulkan dari responden menggunakan kuesioner. Menurut Sugiyono (2008), penelitian survei ini pengumpulan data yang dilakukan menggunakan istrumen kuesioner untuk mendapatkan tanggapan dari responden.

\section{Populasi dan Sampel}

Populasi dalam penelitan ini adalah pelanggan Blend pada bulan Juni 2017 sampai November 2017 yang berjumlah 1.294 orang. Jumlah sampel ditentukan dengan menggunakan rumus Slovin yang berjumlah 100 responden.

\section{Teknik Analisis Data}

Metode analisa yang digunakan adalah uji valditas, uji reliabilitas, tingkat capaian responden (TCR), uji asumsi klasik, uji regresi berganda, dan pengujian hipotesis.

\section{Uji Vadilitas}

Uji validitas dalam penelitian ini digunakan untuk menguji kevalidan kuesioner. Validitas menunjukkan sejauh mana ketepatan dan kecermatan suatu alat ukur dalam kendaraan bermotor Yamaha pada PT. Hasjrat Abadi.

\section{Hipotesis}

1. Diduga brand image berpengaruh positif terhadap keputusan pembelian produk kopi di Blend Coffe.

2. Diduga instagram advertising media berpengaruh positif terhadap keputusan pembelian produk kopi di Blend Coffe.

3. Diduga produk quality berpengaruh positif terhadap keputusan pembelian poduk kopi di Blend

Coffe

melakukan fungsi ukurnya. (Azwar, 2003). Di mana validitas data diukur dengan membandingkan $r$ hasil dengan $r$ tabel ( $r$ product moment), jika :

1. $\mathrm{r}$ hasil $>\mathrm{r}$ tabel, data valid

2. $r$ hasil $<r$ tabel, data tidak valid

\section{Uji Reliabilitas}

Reliabilitas adalah suatu indeks yang menunjukkan sejauh mana hasil suatu pengukuran dapat dipercaya, pada penelitian ini akan menggunakan rumus koefisien Cronbach Alpha. Nilai Cronbach Alpha pada penelitian ini akan digunakan nilai 0.6.

\section{Tingkat Capaian Responden ( TCR ) \\ Statisik deskriptif adalah statisik yang digunakan untuk menggambarkan atau menganlisis suatu data hasil penelitian. Analisis ini memberikan penjelasan tentang subjek yang dibahas tanpa menggunkan perhitungan angka.}

\section{Uji Normalitas Data}

Uji normalitas bertujuan untuk menguji apakah dalam model regresi, dependent variable dan independent variabel keduanya mempunyai distribusi normal 
ataukah tidak. Untuk mendeteksi normalitas data dalam penelitian ini dilakukan dengan uji Kolmogorovsmirnov test.

\section{Uji Multikolinearitas}

Uji multikolinearitas bertujuan untuk menguji apakah pada model regresi ditemukan adanya korelasi antar variabel bebas (Imam Ghozali, 2001). Untuk mendeteksi ada atau tidaknya multikolinearitas di dalam model regresi adalah dengan Menganalisa matrik korelasi variabel bebas jika terdapat korelasi antar variabel bebas yang cukup tinggi (lebih besar dari 0,90 ) hal ini merupakan indikasi adanya multikolinearitas.

\section{Uji Heteroskedastisitas}

Uji heteroskedatisitas bertujuan untuk menguji apakah dalam model regresi terjadi ketidak samaan variance dari residual satu pengamatan ke pengamatan yang lain. Salah satu cara untuk mendeteksi ada atau tidaknya heteroskedastisitas adalah dengan gletser.

\section{Uji Regresi Berganda}

Berdasarkan hubungan dua variabel yang dinyatakan dengan persamaan linear dapat digunakan untuk membuat prediksi (ramalan) tentang besarnya nilai Y (variabel dependen) berdasarkan nilai $X$ tertentu (Variabel independent). Ramalan (prediksi) tersebut akan menjadi lebih baik bila kita tidak hanya memperhatikan satu variabel yang mempengaruhi (variabel independen) sehingga menggunakan analisis regresi linear berganda (Djarwanto, PS, 1989). Adapun bentuk persamaan regresi linear berganda yang digunakan dapat dirumuskan: (Gujarati, 1996).

\section{Persamaan}

$Y=\beta 0+\beta_{1} X_{1}+\beta_{2} X_{2} \beta_{3} X_{3}+e$
Keterangan

$\mathrm{Y}=$ keputtusan pembelian

$\beta 0=$ konstanta

$\beta_{1} \beta_{2} \beta_{3}=$ Koefisien Regresi

$\mathrm{X}_{1}=$ Variabel Brand Image

$\mathrm{X}_{2}=$ Variabel Instagram Advertising

$\mathrm{X}_{3}=$ Variabel Product Quality

\section{Uji Korelasi}

Nilai koefisien korelasi merupakan nilai yang digunakan untuk mengukur kekuatan ( keeratan ) antara variabel. memurut ( Agung Nugroro, 2005 ) memiliki nilai -1 himgga +1 . Sifat nilai koefisien korelasi adalah plus (+) atau minus (-).

Uji F

Uji $F$ digunakan untuk mengetahui pengaruh seluruh variable independen terhadap variabel dependen. Pengujian ini dilakukan pada tingkat keyakinan 95 $\%$ dengan ketentuan sebagai berikut (Ghozali, 2011).Dengan menggunakan nilai probabilitas signifikansi :

a. Jika tingkat signifikasi lebih besar 0,05 maka dapat disimpulkan bahwa Ho diterima, sebaliknya Ha ditolak.

b. Jika tingkat signifikasi lebih kecil 0,05 maka dapat disimpulkan bahwa Ho ditolak, sebaliknya Ha diterima.

Uji t $\begin{array}{rlr}\text { Uji } & \mathrm{t} \text { digunakan untuk } \\ \text { menguji } & \text { pengaruh variabel }\end{array}$ independen secara parsial terhadap variabel dependen. Pengujian ini dilakukan dengan uji t pada tingkat keyakinan 95\% dengan ketentuan sebagai berikut (Ghozali, 2011).

1) Dengan menggunakan nilai probabilitas signifikansi :

a) Jika tingkat signifikasi lebih besar 0,05 maka dapat disimpulkan bahwa Ho diterima, sebaliknya Ha ditolak.

b) Jika tingkat signifikasi lebih kecil 0,05 maka dapat disimpulkan bahwa Ho ditolak, sebaliknya Ha diterima. 
Analisis Koefisien Determinasi $\left(\mathbf{R}^{2}\right)$

Menurut (Ghozali, 2011), koefisien determinasi $\left(\mathrm{R}^{2}\right)$ pada intinya mengukur seberapa jauh kemampuan model dalam menerangkan variasi variabel dependen. Nilai koefisien determinasi berkisar antara $0(0 \%)<$ $\mathrm{R}^{2}<1(100 \%)$.

\section{PEMBAHASAN DAN}

\section{HASIL PENELITIAN}

\section{Uji Vadilitas}

Diperoleh bahwa semua indikator yang digunakan untuk mengukur variabel-variabel yang digunakan dalam penelitian ini mempunyai koefisien korelasi yang lebih besar dari $r$ table $=0,195$ (nilai $r$ tabel untuk $n=100$ ), sehingga semua indikator tersebut adalah valid.

\section{Uji Relibilitas}

Hasil menunjukkan bahwa semua variabel mempunyai Cronbach Alpha yang cukup besar yaitu di atas 0,60 sehingga dapat dikatakan semua konsep pengukur masing-masing variabel dari kuesioner adalah reliabel sehingga untuk selanjutnya item-item pada masing-masing konsep variabel tersebut layak digunakan sebagai alat ukur.

UJI Tingkat Capaian Responden ( TCR)

\section{Brand Image}

Dari Persentasi Penelitian Responden Terhadap Brand Image bisa dilihat bahwa tanggapan

Diketahui bahwa nilai ketiga variabel independen dilihat dari signifikasn $>0,05$ dilihat dari nilai sig yaitu variabel X1 $0,50>0,05, \mathrm{X} 2$ $0,65>0,05$ dan 0,14>0,05. Dengan Uji Regresi Berganda responden cukup baik terhadap semua item

\section{Instagram Advertising Media}

Dari Persentasi Penelitian

Responden Terhadap Instagram Advertising Media Untuk rata-rata semau item 43,36 yang berarti tidak baik.

\section{Product Quality}

Dari Tersentasi Penelitian Responden Terhadap Produtc Quality dengan rata-rata 40,29 yang bermakna tidak baik

\section{Keputusan Pembelian}

Dari Persentasi Penelitian

Responden Terhadap Keputusan Pembelian dengan rata-rata 66,11 yang bermakna cukup baik

\section{Uji Normalitas Data}

Menunjukkan bahwa grafik Normal P-P of Regression Standardized Residual menggambarkan penyebaran data di sekitar garis diagonal dan penyebarannya mengikuti arah garis diagonal grafik tersebut, maka model regresi yang digunakan dalam penelitian ini memenuhi asumsi normalitas.

\section{Uji Multikoloniearita}

Dapat diketahui bahwa nilai tolerance variable independen sebesar 0,622 (X1), 0,733(X2) dan 0,652 (X3) jauh berbeda diatas paotkan 0,10 yaitu 1.608 (X1), 1.364 (X2) dan 1.534 (X3). Hal ini berari bahwa hasil analisis menumjukan tidak ada masalah multikoloniaritas sehingga pengujian layak menggunakan model regresi berganda

\section{Uji Heterokedasti}

demikian dapat di dimpulkan bahwa tidak terjadi masalah pada heterokedastisitas pada model regresi. 
dapat diformasikan persamaan regresinya sebagai berikut:

$Y=1,420+0,488 X_{1}+0,369 X_{2}+$ $0,636 \mathrm{X}_{3}$

Dari persamaan regresi diatas dapat diinterpretasikan sebagai berikut

1. $\beta 0=1,420$ artinya tanpa variabel bebas ( Variabel X ) maka keputusan pembelian produk blend adalah 1,420 dengan asumsi variabel bebas yaitu brand image, Instagram advertising media dan product quality tidak mengalami perubahan

2. $\beta 1=$ koefisien regresi 0,488 menunjukan bahwa setiap variabel Brand Image bertambah 1 poin,maka peningkatan keputusan pembelian konsumen pada produk blend akan bertambah sebesar 0,488 dengan

\section{Uji F ( Goodness of Fit )}

Diketahui nilai signifikansi untuk pengaruh $\mathrm{X}_{1}, \mathrm{X}_{2}, \mathrm{X}_{3}$ secara simultan terhadap $\mathrm{Y}$ adalah sebesar $0,000<0,05$ dan nilai $\mathrm{F}$ hitung

\section{Uji t- statistic ( parsial )}

Uji $t$ padat di lihat Brand Image, Instagram Advertising Media dan Product Quality berpengaruh Analisis Koefisien Derterminasi ( $\mathbf{R}^{2}$ )

\begin{tabular}{|l|l|l|l|l|}
\hline $\begin{array}{l}\text { Mod } \\
\text { el }\end{array}$ & $\mathrm{R}$ & $\begin{array}{l}\mathrm{R} \\
\text { Square }\end{array}$ & $\begin{array}{l}\text { Adjusted } \\
\text { R Square }\end{array}$ & $\begin{array}{l}\text { Std. Error } \\
\text { of the } \\
\text { Estimate }\end{array}$ \\
\hline 1 & $.544^{\mathrm{a}}$ & .296 & .274 & 5.633 \\
\hline
\end{tabular}

Berdasarkan output di atas diketahui nilai Rsquare sebesar 0,296 hal ini menggandung arti bahwa pengaruh variabale $X_{1}, X_{2}, X_{3}$, secara simulat terhadap $\mathrm{Y}$ sebesar $29,6 \%$

PENUTUP

Kesimpulan asumsi variabel brand image dianggap tetap

3. $\beta 2=$ koefisien regresi 0,369 menunjukan bahwa setiap variabel Instagram Advertising Media bertambah 1 poin,maka peningkatan keputusan pembelian konsumen pada produk blend akan bertambah sebesar 0,369 dengan asumsi variabel dianggap Instagram Advertising Media tetap

4. $\beta 3=$ koefisien regresi 0,636 menunjukan bahwa setiap variabel Product Quality bertambah 1 poin,maka peningkatan keputusan pembelian konsumen pada produk blend akan bertambah sebesar 0,636 dengan asumsi variabel dianggap Product Quality tetap

$13,458>\mathrm{F}$ tabel 2,70 sehingga dapat di simpulkan terdapat pengaruh $\mathrm{X}_{1}, \mathrm{X}_{2}, \mathrm{X}_{3}$ secara simultan $\mathrm{Y}$

siginifikan terhadapa keputusan pembelian.

a. Predictors: (Constant), PRODUCT QUALITY ( X3) , ISTAGRAM ADVERTISING MEDIA (X2), BRAND IMAGE ( X1)

a. Dependent Variable: KEPUTUSAN PEMBELIAN ( Y )

dan sisa $70,4 \%$ di pengaruhi oleh veriabel diluar penelitian ini, misalnya promosi, kulitas pelayanan, lokasi

Berdasakan hasil penelitian kepada penggunan product blend di 
café blend padang yang berjumlah 100 orang dikemungkan kesimpulan sebagai berikut. Berdasarkan uaraian pada bab sebelumnya maka penulis mengambil kesimpulan

Dari hasil penelitian uji validitas semuanya valid, dari hasil penelitian berdasarkan uji Reliabel item-item pertanyaan untuk variabel penelitian dapat dipakai sebagai alat ukur dalam penelitian.

Bahwa brand image, Instagram adverting media, product quality, terhadap keptutusan pembelian berpangaruh positif dan

\section{Saran}

1 Blend harus memberikan kualitas terbaik pada produk dan pelayanan serta tetap menjaga citra yang baik di mata pelanggan supaya mereka percaya bahwa Blend tidak akan mengecewakan mereka sehingga mereka akan tetap loyal pada produk Blend.

2. Untuk meningkatkan keputusan pembelian maka disarankan bagaimana meyakinkan konsumen yang dipengaruhi oleh motivasi orang lain, serta meningkatkan keunggulan suatu produk.

\section{DAFTAR PUSTAKA}

Arifin, Ali. 2003. Viral Marketing Konsep Baru Berinvestasi Dan Berwirausaha. Yogyakarta : Andi Publisher.

Buyung, S. (2016). Pengaruh Citra Merek, Kualitas Produk Dan Harga Terhadap Keputusan Pembelian Produk Semen Tiga Roda Di Toko Lico, 16(4), 376386.

Destiana, R. (2015). Pengaruh Citra Merek,Iklan,Dan Kualitas Produk Terhadap Krim Pemutih Pons Disurabaya.
Fiani, M., \& Edwin, S. (2012). Analisa Pengaruh Food Quality Dan Brand Image Terhadap Keputusan Pembelian Roti Kecik Toko Roti Ganep's Di Kota Solo. Jurnal Manajemen Pemasaran, 1(1), 1-6.

Frommer, D. (2010). Here's How To Use Instagram. Diakses Tanggal 5 Juni 2017 Dari Http://Www.Businessinside r.Co.Id/Instagram-2010-11

Ghozali, Imam. 2001. Aplikasi Analisis Multivariate Dengan Program Spss, Bp Undip, Semarang

Hoeffler, Steve., Keller, Kevin Lane. (2003). The Marketing Advantages of Strong Brands. Brand Management, Vol. 10, No.6

Kotler, Philip \& Amstrong, Gary. 2008. Prinsip-Prinsip Pemasaran. Alih Bahasa Bob Sabran M. M. Edisi Bahasa Indonesia. Jilid 1 Dan 2. Jakarta: Erlangga

Marlius, D. Putriani, I. (2019).

Kepuasan Nasabah PT.

Bank Rakyat Indonesia Unit Tapan Cabang Painan

Dilihat dari Kualitas Layanan Customer Service. Jurnal Pundi. Volume 3. No. 2. Hal.111-122. https://doi.org/10.31575/jp.v $3 \mathrm{i} 2.151$

Marlius, D. Ananda, F. (2019). Pengaruh Kualitas Pelayanan Website Akademik Terhadap Minat Kuliah di AKBP Padang. Jurnal Pundi, Vol. 03, No. 03. Hal. 191-204. https://doi.org/10.31575/jp.v 3i3.190 
Marlius, D. (2018). Loyalitas Nasabah Bank Nagari Syariah Cabang Bukittinggi Dilihat Dari Kualitas Pelayanan. Jurnal Pundi. Volume 1. No. 3. Hal.12-22. https://doi.org/10.31575/jp.v $1 \mathrm{i} 3.60$

Marlius, D. (2018). Pengaruh Dimensi Kualitas Pelayanan Website Akademik Terhadap Kepuasan Mahasiswa Pada STIE "KBP". Jurnal Ipteks Terapan. Volume 12. No. 2. Hal. 116-128. http://doi.org/10.22216/jit.2 018.v12i2.633

Marlius, D. RD Putra. (2018). Strategi Pengembangan Sulam Bayang. Jurnal Benefita: Ekonomi Pembangunan Manajemen Bisnis Dan Akuntansi. Volume 3. No. 2. Hal. 204218.

http://doi.org/10.22216/jbe. v3i2.3494

Marlius, D. (2017). Keputusan Pembelian Berdasarkan Faktor Psikologis Dan Bauran Pemasaran Pada PT. Intercom Mobilindo Padang. Jurnal Pundi. Volume 1. No. 1. Hal. 5766.

https://doi.org/10.31575/jp.v $1 \mathrm{i} 1.9$

Marlius, D. (2016). Pengaruh Bauran Pemasaran Jasa Terhadap Minat Nasabah Dalam Menabung Pada Bank Nagari Cabang Muaralabuh. https://doi.org/10.31227/osf. io/vdqgx

Lubis, Ikhsan Bismo Hidayat. (2016). Pengaruh Citra Merek,Media Iklan
Instagram, Dan Persepsi

Kualitas Terhadap

Keputusan Pembelian

Produk Vans (Studi Kasus

Pada Followers

Twitter@Vheadid).

Mccarthy, E.J. (1985). Dasar-Dasar

Pemasaran. Diterjemahkan

Sugiyono. 2008. Metodelogi Penelitian Bisnis. Bandung: Alfabeta

Susanti, F., \& Gunawan, A. C. (2019). Pengaruh Bauran Promosi Dan Harga Terhadap Keputusan Pembelian Produk Kosmetik Maybelline Di Kota Padang. https://doi.org/10.31227/osf. io/npjqh

Mayliza, R. (2019). Pengaruh Citra Perusahaan (Corporate Image) Dan Penanganan Keluhan (Complaint Handling) Terhadap Loyalitas Pelanggan (Loyality) Natasha Skin Care Di Kota Padang. https://doi.org/10.17605/OS F.IO/DF9XJ

Mayliza, R. (2019). Pengaruh Kesadaran Merek, Asosiasi Merek Dan Perception Of Quality Terhadap Keputusan Pembelian Hospital Bed Merek Paramout Di PT. Aga Medika Utama Padang (Studi Kasus Rumah Sakit Umum Kota Padang). https://doi.org/10.17605/OS F.IO/VYQ4E

Pranata, H. I., \& Mayliza, R. (2019). Pengaruh Komunikasi Pemasaran Terpadu Dan Ekuitas Merek Terhadap Loyalitas Konsumen Pada CV. Laris Motor Cabang 
Air

Haji.

https://doi.org/10.31219/osf. io/d9qsu

Anggara, A., \& Mayliza, R. (2019). Pengaruh Ketidakpuasan Konsumen, Karakteristik Kategori Produk HP, Terhadap Keputusan Perpindahan Merek Pada Mahasiswa Regular Program Studi Manajemen Angkatan 2014-2015 STIE "KBP" Padang. https://doi.org/10.31219/osf. io/yfuzh

Ulfa, M., \& Mayliza, R. (2019). Pengaruh Kualitas Pelayanan Dan Kepuasan Pelanggan Terhadap Loyalitas Pelanggan PDAM Kota Padang. https://doi.org/10.31219/osf. io/spmgv

Mayliza, R. (2019). Analisis Keputusan Pembelian Ulang Axis Ditinjau Dari Bauran Pemasaran Kasus Di Kota Padang. https://doi.org/10.31219/osf. io/e7xhy

Mayliza, R. (2019). Kajian Kredit Melalui Perencanaan Dan Pengendaliannya Kasus Pada PT. Bank Perkreditan Rakyat Batang Tarusan. https://doi.org/10.31219/osf. io/h3j6m

Mayliza, R. (2019). Analisis Customer Satisfaction Dan Behavioral Intention Dilihat Dari Service Quality, Food

Quality Dan Price/Value Di

Restoran Mc Donald's Depok.

https://doi.org/10.31219/osf. io/e2jrt

Putra, Y. E., \& Aziz, N. (2019). Pengaruh Kualitas

Pelayanan Dan Kepuasan

Pelanggan Terhadap

Loyalitas Nasabah PT. Bank

Rakyat Indonesia Cabang Padang.

https://doi.org/10.31219/osf. io/hcsw2

Fernos, J., \& Putra, Y. E. (2019). Analisa Pengaruh Kualitas Pelayanan Terhadap Kepuasan Nasabah Pada PT. Bank Mega Syari'ah Padang. https://doi.org/10.31219/osf. io/y2baf

Sulistyawati, P. (2011). Analisis Pengaruh Citra Merek Dan Kualitas Produk Terhadap Keputusan Pembelian Laptop Merek Acer Dikota Semarang. Manajemen, 125.

Tjiptono, Fandy. (2001). Strategi Pemasaran Edisi Pertama. Yogyakarta: Andi Offse

Zimri, O.:, Mawara, R., Ekonomi, F., Manajemen, J., Sam, U., \& Manado, R. (2013). Periklanan Dan Citra Merek Pengaruhnya Terhadap Keputusan Pembelian Kendaraan Bermotor Yamaha, 1(3), 826-83. 